\title{
Macroeconomic indicators analysis for energy sustainability
}

\author{
A. Martínez ${ }^{1}$, C. Senabre ${ }^{1}$, S. Valero ${ }^{1}$, E. Velasco ${ }^{1}$ and C. Sans \\ ${ }^{1}$ Department of Mechanical and Energy Engineering \\ E.P.S., Miguel Hernandez University \\ Elche, 03202 Alicante (Spain) \\ Phone/Fax number:+003496665890, e-mail: alberto.martinez@umh.es, svalero@umh.es
}

\begin{abstract}
Attempts to model the energy behaviour of states may be are not yet sufficiently precise and adaptable to the different junctures of states because of the large number of variables and possible scenarios.

Although there are indices and models for evaluating sustainability, many of them focus on highly aggregated quantitative variables. Even though not considering the energy dimension, the main objective of this work, these variables are recognized by international organizations.

The article focuses on evaluating variables from the subsystem of energy sustainability with the three dimensions of sustainable development: nature, economy and society. Descriptive statistics have been used, which allows, in a simple way, to interpret the data for tacking decision about energy policy.
\end{abstract}

\section{Key words}

Energy, indicators, electricity, productivity, efficiency, sustainability.

\section{Introduction}

Any approach to sustainable energy strategies should be analysed considering fundamental concepts such as:

- Security and quality of supply: to satisfy an increasingly changing energy demand in appropriate conditions, respecting the environment and biodiversity considering the impact of the use of energy in any of its forms;

- Promoting sustainable economy: taking into account the efficiency of processes, organizations and individuals, as well as the social responsibility of the productive sectors, as generators of employment;

- Guaranteeing social equity in all its forms, with universal access to energy at reasonable costs, while boosting energy markets, making them more efficient and competitive.
Energy policies must be defined, through the use of appropriate technologies, to promote the prosperity of humanity and its progress towards the knowledge of society. To the determination of the variables of the suitability it must be studied firstly conjunctures such as: economical, energetic, territorial and social from the different countries.

Not all the variables will be the most suitable to carry out an analysis of the energy situation in the different nations, taking into account the concept of local sustainability.

We should not study only the energy sustainability variables. We should study variables of sustainability that will be appropriate to different countries conjunctures

There are very different geopolitical aspects in other continents such as: the existence of very different levels of environmental commitments or the different levels of protection of human rights. Therefore, the European Union will be established as the reference continent for analysis.

This work is based on five main areas of decision:

- Environment (emissions and pollution),

- Economy (growth)

- $\quad$ Society (energy demand)

- $\quad$ Security of supply

- Regulation of markets

With this research a model of indicators is proposed to control the compliance of energy sustainability.

However, different thresholds are established that will determine the degree of commitment of the countries. Ratios of energy variables will be established for countries with specific competitiveness and productivity per capita. These ratios will allow grouping the countries that initially could not be included in the initial aggregation. 


\section{Structure of energy sustainability for governance.}

Government policies on the energy sector must always take into account these areas: government, productive sectors, administration, citizens and social agents ... etc. Therefore the energy sector is also a country issue. In addition, a country's energy governance has connections to many policies such as: trade, infrastructure, environment, transportation, finance, etc.

All of these areas can be summarized in three major groups in energy policy:

- The education and culture (social dimension): healthy habits in the use of energy should be promoted at schools. Moreover, actions to disseminate information to citizens about healthy habits from the point of view of energy consumption should be considered to ensure the access of everyone to the energy with equity.

- Energy efficiency and the use of clean technologies (nature dimension): the EU has to face the decarbonisation of the mix and to reduce the energy demand [1 and 2].

- The issue of the connection between economic, energy and environmental interests: there is a risk that economies with an intensive energy consumption will face an unequal competition [3] because, in the future, there will be a polarization of demand of energy by the emerging countries that will increase to a one-third of the world energy consumption between 2035 and 2040 [45].

There are great contrasts when using per capita electricity consumption ratio per year. For example: in Bangladesh, the average consumption per person is $0.2 \mathrm{MWh}$, in India of 0.7 MWh, in Germany of $7 \mathrm{MWh}$, in the United States $13 \mathrm{MWh}$ per person vs year [6-7]. For this reason, indicators for decision-making in developing countries should be significantly different from more advanced economies.

Then, the analysis is organized around the three dimensions of sustainable development with its descriptors corrected in terms of energy sustainability: environment (emissions and pollution), economy (growth) and society (energy demand) explained in the previous paragraph.

Moreover, analysing the subsector of energy sustainability [8] two new dimensions should be taken into account: security of supply and regulation of markets, as shown in Figure 1.

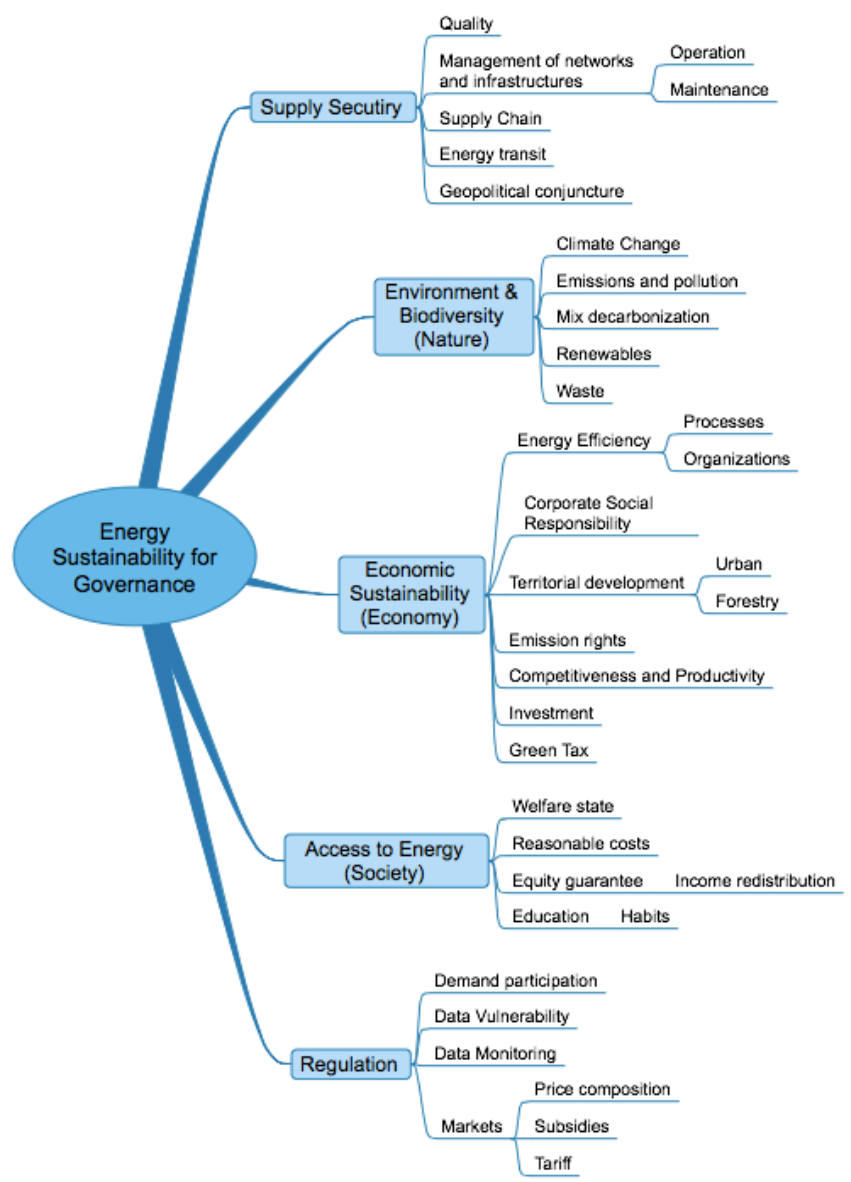

Figure 1. Energy Sustainability for Governance. Source: own elaboration

As it can be seen in Figure 1, for the analysis of the energy sustainability, two new variables should be taken into account for taking decisions by the governance:

- The security of supply: with strategic importance for the energy sector but also for parameters such as: energy transit, supply logistics, management of technology networks and infrastructures. These quality parameters were established for each of the different forms of energy,

- The degree of self-sufficiency or external energy dependence: This is a fundamental concern of the energy policies of many countries. From this variable the rest of the indicators can be disaggregated.

On the other hand, all the aspects that concern to the regulation of the markets have high relevance as instruments of sustainable management of the energy. The wholesale market is important because can vary the structure of price formation from the offer, and the retail market affect to the regulation of the tariff of access or formulas of demand management in the different sectors of energy consumption such as: transport, industry, commerce, services, edification etc...

The huge volume of data (the Big Data) from the energy sector and specifically from the electricity sector cannot be treated in a conventional way because it is necessary to guarantee the safeguarding of the identities of users. These data will be used for the regulation and markets. 
The Big Data will permit the acquisition and the process of user of data the information management and also taking energy decisions by telecommunications sector. Although the degree of exposure of the user data should be assessed, the emergence of the information and communication technologies in the energy sector is decisive for establishing the maturity of markets and their regulation. Even though many questions should be answered about the way that information management will affect market behaviour and new regulatory scenarios, the electricity sector will undoubtedly benefit from a strong dynamism with good management of existing technologies that can create a new paradigm. Therefore, as a fundamental indicator of aggregation, the Technical Intensity of the energy system is defined.

As a third major area to be considered by the governance for energy sustainability is the protection of the environment and climate in all its aspects. This area consider all those actions that must make our biodiversity sustainable, such as: monitoring the consequences of climate change, promoting the reduction of emissions and pollution, promoting the decarbonisation of the mix, developing the energy from renewable sources, defining new policies for waste recycling, and implementing and developing environmental management tools. Therefore, $\mathrm{CO} 2$ emissions are an aggregate indicator to discern the families of indicators. This indicator is important due to its diversification and its international recognition.

The fourth major area is the sustainable economy; it includes the actions such as: boosting investment, territorial and water policy [8], policies of efficiency, taxation, financial and improving the competitiveness of companies that allow a stable framework to promote investments from the private sector. The sustainable economy requires efforts in the development of products and services that take into account the entire life cycle from conception and design to disappearance. It is required a culture of efficiency at all levels. Companies acquire a preponderant role in the sustainable economy and in particular implanting the concept of Corporate Social Responsibility, which also focuses its methodology around the three dimensions of sustainable development. To control this important area the parameter that will determine the disaggregation is the Energy Intensity of the Economy.

The fifth major area is the society and access to energy; it is the core of sustainable development. Without the access to the energy there can be no human progress, and much less if it occurs in conditions of unsustainability. It is important to remember that there are great contrasts in the world in relation to access to energy. The report on the Millennium Development Goals [9] already clearly articulates the link between the progress of society and energy; it also proposes investment needs to reach the targets estimated at USD 15 per capita and year 20062015. According to the report "Sustainable Energy for All 2015 - Progress Toward Sustainable Energy" [10] global investment will increase its needs five times in the coming years: from USD 9 trillion in 2012 to USD 45 in 2030.
It is also important to highlight the United Nations initiative on the 17 Sustainable Development Goals [11]. This initiative will include ensuring access to affordable, secure, sustainable and modern energy for all. Finally, as a main indicator on which to establish the disaggregation it will be determined the Social Progress Index corrected.

\section{The three dimensions dissociation}

On the top of that, it is necessary to develop a group of indicators related to the energy field that is integrated in the decision tree of Figure 1. The figure is focused on the dissociation of the three pillars of sustainable development: nature, economy and society. These pillars acquire a new definition in the field of energy sustainability: demand for energy, economic growth and emissions see Figure 2. Seeing Figure 2 it cannot be said that economic growth implies a greater consumption of energy and an increase in the polluting activities of human actions because this will be a source of unsustainability. Therefore, for the existence of energy sustainability, it is necessary to create dissociation between these three pillars, or at least, between growth and energy demand, this can be denominated "dematerialization". The sustainability that occurs when reducing energy consumption increasing growth, should accompany the reduction of the volume of waste and emissions generated.

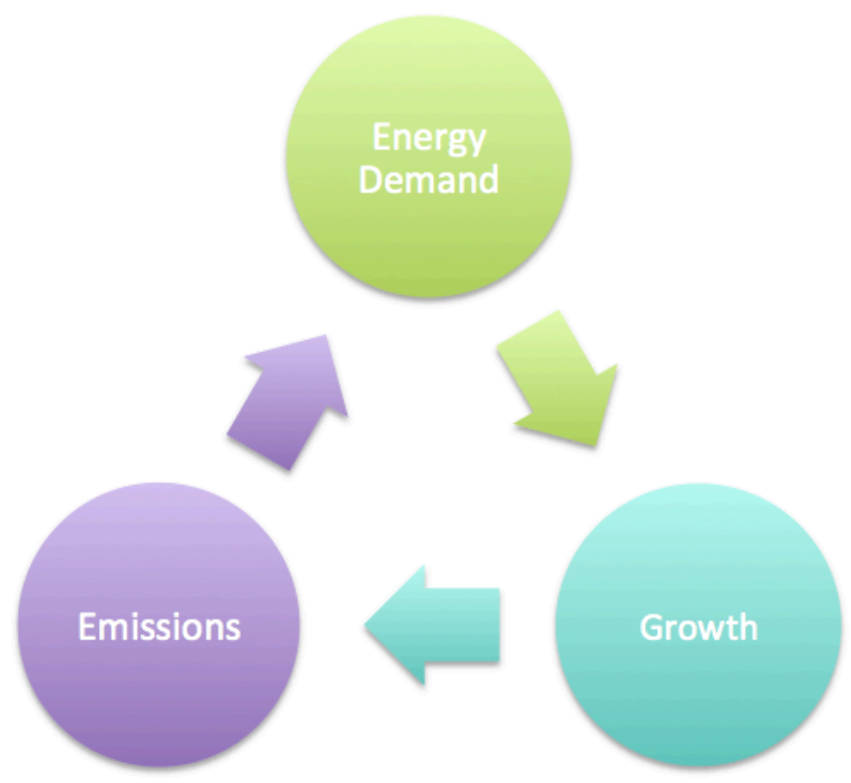

Figure 2. The three pillars of energy sustainability. Source: own elaboration.

\section{Setting metrics for governance and selection of countries of the study}

There are independent indicators of the energy performance of systems such as: Energy Intensity of the Economy [12], Energy Return on Energy Invested [13] and [14], or even more sectoral indicators such as: those related to social poverty and its energy implications [15] that provide information to evaluate the energy performance of a system. 
But a variable interpreted in isolation can be misleading, for instance, about areas like Energy Intensity of the Economy, countries like Nigeria, Kazakhstan or Zambia have the highest rates in the world [7], but in other areas such as: human rights, employment, technological development, welfare state, are far behind other developed countries with much lower energy intensity indices. It is also important to observe the indicators in relative terms: per capita energy consumption, energy intensity of the economy, per capita GDP, etc., which will be very suitable for comparisons between nations, but without losing the absolute values perspective. Definitely, the reduction of energy consumption and therefore energy efficiency, is a common goal to achieve energy sustainability and, ultimately, sustainable development.

The three remarkable to consider in determining the variables for determining characteristics indices are as follows: first, define a broad series that makes available an observation consistent with the nature of the variable. Second, have updated, reliable and consistent information that allows comparison between different countries by obtaining data with the same methodology. Third, the data must have a sufficient level of disaggregation for observing behavior patterns or patterns in the series that compose them. Some of the correlations obtained in the analysis are not conclusive because the series of data obtained, with a very small final sample size, greatly complicates the validation of the results. Therefore, larger series should be obtained to validate the model.

For the determination of the variables firstly we should question their suitability [8] to the different economic, energy, territorial and social conjunctures of the different countries, that is to say, not all variables will be the most suitable to carry out an analysis of the energy situation in the different nations taking into account the concept of local sustainability [16]. For example, a region such as Western Europe, where there is a great dependence on energy from abroad and a very relevant contribution of the electricity sector to the final energy available, we should evaluate variables that will have nothing to do with those needed for the Central African region, whose electrical dependence is much lower. Somalia, a country where agriculture accounts for $60.2 \%$ [17] of its GDP, has a completely different energy situation to the United Kingdom, whose agriculture represents about 1\% [18] of GDP. Therefore, we should not talk so much about energy sustainability variables, but about families of sustainability variables that will be appropriate to different countries' conjunctures.

Considering very different geopolitical aspects in other continents, such as: the existence of very different degrees of environmental commitments or the different level of protection of human rights, finally, the European Union will be established as the reference continent for the analysis. Moreover, in this paper we will also discard the variable of the composition of the different productive sectors, analysing countries with a similar income per capita, and with a similar specific weight of their economic sectors: the tertiary or service sector, industrial and agriculture and livestock (Figure 3).
In addition, other variables intrinsic to this structure will provide more equity to nations, such as: health, educational and social service coverage, a similar level of infrastructure and communications, and a similar situation in defence and human rights.

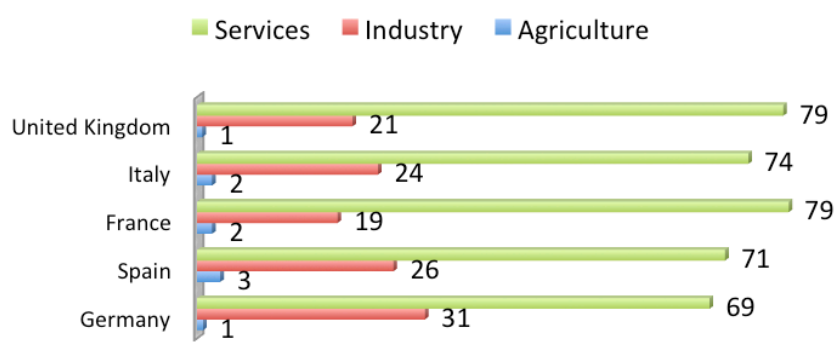

Figure 3. Productive sectors PIB contribution in $2012(\%)$ Source: CIA [17], EUROSTAT [18], IMF [19] \& own elaboration

On the other hand, from the point of view of infrastructures, it is noteworthy those economies with a similar structure of the transport sector (evaluating indicators such as: freight transport activity or distance travelled per capita or even $\mathrm{CO} 2$ emissions from that sector) will also facilitate a homogenization in the comparison of prices and energy consumption. It will also be taken into account the territorial conjuncture with perspectives such as: the degree of self-sufficiency of energy, as well as the distribution of the population (per capita housing area, residential and tertiary sector). These parameters will also allow establishing similarities that will facilitate the comparison of variables and obtain behaviour patterns.

The comparable countries will be those that have their parameters of conjuncture framed in clusters based on the previous indicators. The range of countries defined for the study and based on these parameters are: Germany, France, Italy, United Kingdom and Spain.

In this case of study, the aspects related to access to electricity, water, and per capita housing are similar, but in terms of per capita income, there are some differences, which would lead to a possible differentiation into two groups on several occasions: on the one hand: Spain and Italy, and on the other hand: France, Germany and UK.

For the research, different thresholds will be established to determine the degree of commitment of the countries and also regarding to the population that would discard in the joint analysis to Germany and Spain.

However, when establishing ratios of energy variables and per capita specific competitiveness and productivity, it will be possible to group the countries that initially could not have an aggregation. 


\section{Summary of indicators for the energy sustainability of nations}

In the previous sections, it has been made an approach to the indicators that represent energy sustainability from the dimensions of sustainable development. In summary, the indicators are:

Table I. Indicators and sub-indicators. Source: own elaboration

\begin{tabular}{|c|c|c|}
\hline Indicators Family & General Indicator & Sub-indicators \\
\hline $\begin{array}{l}\text { Sustainable } \\
\text { economic growth }\end{array}$ & EIE & $\begin{array}{c}\text { GDP, GDP per } \\
\text { capita, IPI, ASAI, } \\
{ }^{*} \text { TE }\end{array}$ \\
\hline Energy demand & $\mathbf{E D}_{\mathrm{UE}}$ & $\begin{array}{c}\text { GDP, GDP per } \\
\text { capita, PEC, }{ }^{*} \text { PE }\end{array}$ \\
\hline $\begin{array}{l}\text { Regulation and } \\
\text { markets }\end{array}$ & $* \mathrm{TI}_{\mathrm{ES}}$ & EIE, FEC, PED \\
\hline $\begin{array}{l}\text { Environment and } \\
\text { diversity }\end{array}$ & GGEPC & GGE, EI $I_{E U}, \mathbf{E}$ \\
\hline
\end{tabular}

$\begin{array}{lll}\text { Access in equity } & \text { SPI }_{\mathbf{C}} & \mathbf{O D S}_{7}, \mathrm{HDI}\end{array}$

* Note: Referred indexes are contributions of the article

Where:

- EIE, Energy Intensity of the Economy (ktep / €)

- GDP, Gross Domestic Product (€)

- IPI, Industrial Production Index (\%)

- ASAI, Activity Sector Activity Indicator (\%)

- *TE, Technical Efficiency of a given economic sector (ktep / €)

- $\mathrm{ED}_{\mathrm{EU}}$, Energy Dependence (\%)

- PEC, Primary Energy Consumption (ktep)

- * $\mathrm{PE}_{\mathrm{SE}}$, Primary Energy System Efficiency (\%)

- * $\mathrm{TI}_{\mathrm{ES}}$, Technical Intensity of the energy system (\%)

- FEC, Final Energy Consumption (ktep)

- PED, Primary Energy Demand (ktep)

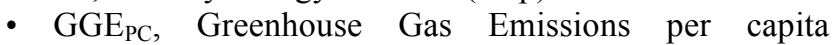
$\left(\mathrm{kgeCO}_{2} / \mathrm{h}\right)$

- GGE, Greenhouse Gas Emissions $\left(\mathrm{kgeCO}_{2}\right)$

- $\mathrm{EI}_{\mathrm{EU}}, \mathrm{CO}_{2}$ emission intensity according to Eurostat methodology $(\mathrm{kgCO} 2 / €)$

- E, Total CO2 Emissions (tons)

- $\mathrm{SPI}_{\mathrm{C}}$, Corrected Social Progress Index (\%)

- $\mathrm{ODS}_{7}$, Millennium Development Goal 7 on energy

- HDI, Human Development Index (\%)

The mathematical expression that defines the General Index of Energy Sustainability (GIES) [20] adds all the general indicators once normalized, according to the following expression:

$$
G I E S_{t}^{i}=\frac{E I E_{t}^{i}}{140}+E D_{U E_{t}}^{i}+\left(100-T I_{E S_{t}}^{i}\right)+\frac{G G E_{t}^{i}}{0,4}+\left(100-S P I_{c t}^{i}\right)
$$

Where:

$G I E S_{t}^{i}$, General Index of Energy Sustainability

$E I E_{t}^{i}$, Energy Intensity of the Economy (ktep / €)
$E D_{U E_{t}}^{i}$, Energy Dependence (\%)

$T I_{E S}{ }_{t}^{i}$, Technical Intensity of the energy system (\%)

$G G E_{P C_{t}}^{i}$, Emissions of Gases Greenhouse effect per capita $(\mathrm{kgeCO} 2 / \mathrm{h})$

$S P I_{C}{ }^{i}$, Corrected Social Progress Index (\%)

The standardization of indicators [20] is done in order to achieve their aggregation in a General Index of Energy Sustainability (GIES). Applying the principles of sustainability, justifies a standardization of indicators so that greater sustainability will correspond to a lower surface impact. For example: the smaller area of representation of the general indicators in an omnidirectional polar diagram, the greater sustainability will be obtained. All the indicators and sub-indicators are parameters that are known with certainty. Therefore, it is a deterministic model.

Finally, according to the table below, where the final values of the General Index of Energy Sustainability (GIES) for 2014 are collected, the country with the best sustainable performance would be the United Kingdom, followed by France and Italy. To the tail of sustainability we would have to Germany and Spain.

Table II. General Index of Energy Sustainability (GIES) in 2014. Source: own elaboration

\begin{tabular}{cccccc}
\hline 2014 & Germany & Spain & France & Italy & UK \\
\hline EIE & $\mathbf{8 1 , 5 7}$ & $\mathbf{8 0 , 5 0}$ & $\mathbf{8 5 , 8 6}$ & $\mathbf{6 9 , 9 3}$ & $\mathbf{6 8 , 4 3}$ \\
ED $_{\text {UE }}$ & $\mathbf{6 1 , 6 0}$ & $\mathbf{7 2 , 9 0}$ & $\mathbf{4 6 , 1 0}$ & $\mathbf{7 5 , 9 0}$ & $\mathbf{4 5 , 5 0}$ \\
TI $_{\mathrm{ES}}$ & $\mathbf{3 3 , 2 6}$ & $\mathbf{3 2 , 1 0}$ & $\mathbf{4 2 , 9 6}$ & $\mathbf{2 4 , 9 5}$ & $\mathbf{3 1 , 4 7}$ \\
GGE $_{\mathrm{PC}}$ & $\mathbf{6 4 , 1 4}$ & $\mathbf{5 2 , 2 8}$ & $\mathbf{3 0 , 1 7}$ & $\mathbf{4 3 , 8 5}$ & $\mathbf{4 5 , 5 2}$ \\
SPI $_{\mathrm{C}}$ & $\mathbf{2 1 , 2 1}$ & $\mathbf{2 8 , 5 4}$ & $\mathbf{2 5 , 9 2}$ & $\mathbf{3 1 , 8 8}$ & $\mathbf{2 2 , 7 1}$ \\
TOTAL & $\mathbf{2 6 1 , 7 8}$ & $\mathbf{2 6 6 , 3 2}$ & $\mathbf{2 3 1 , 0 1}$ & $\mathbf{2 4 6 , 5 1}$ & $\mathbf{2 1 3 , 6 4}$
\end{tabular}

\section{Conclusion}

In the present work a model of suitable indicators is established from the concept of Energy Sustainability in five large areas, to perform the disaggregation of indicators. These five major areas are: security of supply, regulation of demand and markets, access to energy for equity, growth promotion and sustainable economic development, and finally, respect for the environment and diversity.

It proposes a General Index of Energy Sustainability (GIES) composed of the general indicators defined for each of the five representative areas of energy sustainability. The lower the value of the GIES, the greater the sustainability obtained.

Three new indicators are proposed, the third of them, as a general indicator of the area of regulation of demand and markets, one of the five areas of energy sustainability: 
1. TE, Technical Efficiency of a given economic sector (ktep / €)

2. $P E_{\mathrm{SE}}$, Primary Energy System Efficiency (\%)

3. $\mathrm{TI}_{\mathrm{ES}}$, Technical Intensity of the energy system (\%)

The GIES allows overcoming the interpretation of the indicators independently, since it takes into account the multiple facets of energy sustainability. For example, Energy Intensity of the Economy (EIE), is not an indicator that alone can show a sustainable behaviour or not of the countries and their activity. Since a positive evolution of this indicator may not mean an improvement in the country's energy sustainability conditions, but rather a simple reduction of energy demand in the face of a scenario such as economic crisis.

In addition, the different economic, energy, territorial and social conjunctures of the different countries make the model to adapt, for instance, not all variables will be the most suitable to carry out an analysis of the energy situation in the different nations. New sub-indicators should be defined within the five broad areas, which are appropriate to the different national situations.

\section{References}

[1] Leal-Arcas, R. Designing International Trade in Energy Governance for EU Energy Security. Legal Studies Research n197. Queen Mary University of London, School of Law. 2015

[2] OECD/IEA [on-line] International Energy Agency - World Energy Outlook - Resumen Ejecutivo- 2014

[3] Grossman, Gene M.; Krueger, Alan B. Economic Growth and the Environment. The Quarterly Journal of Economics 110-2 (253-377) - 1995

[4] OECD/IEA [on-line] International Energy Agency - World Energy Outlook - Resumen Ejecutivo- 2013

[5] OECD/IEA [on-line] International Energy Agency - World Energy Outlook - Resumen Ejecutivo- 2015

[6] Nieto, J.; Linares, P. Cambio Global en España 2020-2050. Energía, Economía y Sociedad. Centro Complutense de Estudios e Información Ambiental - Fundación CONAMA. Centro Complutense de Estudios e Información Ambiental. Asturias 2011

[7] Grupo Banco Mundial [on-line] Datos de libre acceso del Banco Muncial. http://www.bancomundial.org - 2017

[8] A. Martinez, S. Valero, C. Senabre, E. Velasco, "Sustainability as a Paradigm of Energy Policy" Renewable Energy and Power Quality Journal (RE\&PQJ) ISSN 2172-038X, $\mathrm{n}^{\circ} 14$ - May 2016

[9] UN - Millenium Project. Invirtiendo en el desarrollo. Un plan práctico para conseguir los Objetivos del Desarrollo del Milenio. Naciones Unidas - Nueva York. 2005
[10] IEA/WB - International Energy Agency and the World Bank. Sustainable Energy for All 2015-Progress Toward Sustainable Energy. Ed. World Bank. Washington, DC. 2015

[11] UN - Sustainable Development Goals [on-line]. Sustainable Development Goals. 17 Goals to Transform our World 2016 [Consulted in 2017]. Available at: http://www.un.org/sustainabledevelopment/

[12] Análisis de la evolución de la intensidad energética en España, Economics for Energy, 2010, ISSN 2172-8127

[13] Deng, S.; Tynan, G.R. Implications of Energy Return on Energy Invested on Future Total Energy Demand. Sustainability 2433-2442. 2011

[14] Henshaw, P.F.; King, C.; Zarnikau, J. System Energy Assessment (SEA), Defining a Standard Measure of EROI for Energy Businesses as Whole Systems. Sustainability 19081943.

2011

[15] Nussbaumer, O.; Nerini, F.F.; Onyeji, I.; Howells, M. Global Insights Based on the Multidimensional Energy Poverty Index (MEPI). Sustainability 2060-2076. 2013

[16] Naredo, J.M. Sobre el origen, el uso y el contenido del término sostenible. Ministerio de Obras Públicas, Transportes y Medio Ambiente. La construcción de la ciudad sostenible. Madrid - 1996

[17] CIA - Central Intelligence Agency [on-line]. The world Factbook [Consulted in 2013]. Available at: https://www.cia.gov/library/publications/the-worldfactbook/fields/2012.html

[18] EUROSTAT [on-line] - European Commission Statistics Database. Available at: http://ec.europa.eu/eurostat/web/main/home

[19] IMF [on-line] International Monetary Fund - World Economic Outlook Databases (WEO) [Consulted in 2013]. Available at: http://www.imf.org/external/data.htm

[20] Martinez, A. Análisis de Indicadores Macroeconómicos para la Sostenibilidad Energética. PhD Thesis - 2017. Universidad Miguel Hernández 